\title{
PROGRESS IN BRITISH BROADCASTING
}

$\mathrm{T}$ HE annual report and statement of accounts of the British Broadcasting Corporation for the year ended March 31, 1960, comprises a general review of the year, the reports of the Broadcasting Councils for Scotland and for Wales, chapters on programme output, regional broadcasting, audience research, external broadcasting, engineering, staff and contractual matters, publications and finance, together with a series of appendixes and tables*. Matter of scientific interest is contained mainly in the general review and in that on engineering. The general review notes that plans are ready for substantial advances in sound broadcasting, which shows every sign of maintaining a hold on the public in its own right and as a service complementary to that of television. In the overseas and international spheres, further developments and possibilities lie ahead for the Corporation, especially in the field of television, and, generally, the Corporation considers that it has gone a considerable way to map out the courses that it should follow and the programme of development that will be needed during the next five to ten years.

The Corporation welcomes the Government's decision that during 1961-62 the full net proceeds of the licence revenue, apart from the $£ 1$ excise duty, should be devoted to broadcasting. However, the retention by the Treasury of 5 per cent of this revenue in the current financial year has necessitated the slowing down or postponement beyond 1960-62 of some projects which the Corporation regards as highly desirable, and which it wishes to complete at the earliest possible date. During the year the number of householders with combined licences for sound and television rose from $9,255,422$ to $10,469,753$, and that of those with licences for sound only decreased from $5,480,991$ to $4,535,258$. About 97 per cent of the population of the United Kingdom are now within range of the VHF sound broadcasting network, and it is estimated that rather more than one household in five has a VHF receiver. In sound, as in television, the Corporation is planning to provide or improve coverage in certain difficult areas by building lowpower satellite stations, and schemes have also been prepared both for a further extension of coverage and also for introducing a system of local broadcasting on VHF. Audience research indicated that adult viewers with a choice of BBC and ITV were devoting some 37 per cent of their evening viewing time to BBC programmes in the last quarter of the year, compared with 32 per cent in the first quarter.

Experience gained during the past eleven years suggests that the restriction on broadcasting imposed by Section 63 of the Representation of the People Act, 1949, is now out of date, and the report expresses the hope that action will be taken to amend the Act accordingly. In science broadcasting, Prof. Medawar's Reith Lectures took an outstanding place, and upwards of 150 leading scientists took part in science programmes in sound radio during the year, while in television "Eye on Research", in which scientists

* Annual Report and Accounts of the British Broadcasting Corporation, 1959-60. Pp. 175+8 plates. (Cmnd. 1174.) (London H.M. Stationery Office, 1960.) 98 , net. in many fields demonstrate their equipment and research techniques and explain the work that they are doing, was the main continuing contribution. From time to time, however, the full resources of television are deployed on some major scientific theme, but the series of televised scientific demonstrations given by Sir Lawrence Bragg in the main lecture theatre of the Royal Institution were also highly appreciated by viewers. Preparations went forward throughout the year for the increase in output of the school television service to take place in the 1960-61 school year, and the scope of the service will also be extended to cover some of the special needs of primary schools and of the sixth forms of grammar schools.

Referring to regional broadcasting, the report expresses the view that if full advantage is taken of the opportunities for development, in adjustment to the changing neods of the time, regional activities in sound will form an enduring part of the overall pattern of the Corporation's broadcasting; but, while sharing fully the desire of the Broadcasting Council for Wales for an allocation of frequencies which would permit a separate television transmitter for South Wales, the Corporation has been unable to take the necessary steps because of the insufficiency of channels available. At present the Corporation's television service covers 98.8 per cent of the population of the United Kingdom, but the technical problems in bringing this to 100 per cent are formidable and are discussed in some detail in a special section of the review dealing with future tasks. The first of these is seen as the extension and improvement of transmitter coverage in areas where reception, whether of sound or television programmes, is unsatisfactory or non-existent. For television the only frequencies that could be readily applied for this purpose are the as yet uncommitted channels in Band III, and if the Government decides that these should be used for an additional television service, the Corporation wishes to provide the additional service. Apart from giving viewers a genuine alterna. tive service, this second service would enable the Corporation to increase the number of serious, cultural and informative programmes, to cater more fully for regional needs, to extend educational broadcasts, and to provide more opportunity for experimental programmes. The Corporation believes that a move into Bands IV and V, which is an essential condition for a change in television standards, can be made successfully only if the public has the incentive of one or more new programmes in these bands. Given the necessary frequencies and finance, the Corporation would be prepared to start a new service in these bands and also if the Government so decided to start a service of colour television in Bands $\mathrm{I}$ or III, taking advantage of the experience it has already acquired and of the many experimental transmissions it has made in colour using the present 405-line standard. The Corporation claims that it could start a second television service in Band IV if it were granted the full proceeds of the present $£ 4$ licence, and that full development of the Corporation's ser- 
vices in sound and television, including a new television service in Bands IV and V and of colour, would call for a combined licence at about $£ 5$.

Under engineering research and development, the report notes that a comprehensive report has been prepared for publication on a series of experimental transmissions in Band $\mathrm{V}$ which included a comparison of the existing British 405-line standard and the Continental standard of 625-lines. The regular experimental stereophonic transmissions, commenced in 1958, have been continued, and the Corporation is investigating possible systems of broadcasting both stereophonic channels from a single VHF transmitter in such a way that monophonic reception is not impaired. Research continued into various aspects of videotape recording as well as investigation of the propagation properties of the ionosphere, for purposes of day-today operation of the Corporation's short-wave services, and considerable effort has been directed to the design of equipment using transistors instead of valves, although in broadcasting, and particularly in television, it is difficult to obtain the same high standard of performance from transistors as can be obtained from valves. Nevertheless, in almost all new portable or mobile audio-frequency equipment, and also in fixed equipment designed to operate independently of the public mains supply without large and costly batteries, it is possible and advantageous to use transistors.

While there is a marked potential audience for the Corporation's external broadcasts, to which the development of transistor receivers, cheap and easy to run, has made an important contribution, especially for medium-wave transmissions, Communist China has now displaced the $\mathrm{BBC}$ as the third largest external broadcaster. The services have been extended in certain directions, but rising costs and the stringent limitation of grants by the Government have offset the expansions by reductions elsewhere, and the report stresses the challenge which faces external broadcasting from the United Kingdom. In meeting it, the Corporation's international reputation for reliability and independence, its long experience and its established position as a source of programmes regularly heard and re-broadcast throughout the world are solid advantages, but they require ample technical support, particularly by way of higherpowered transmitting stations in the United Kingdom and more relay stations overseas. When this is forthcoming, the $\mathrm{BBC}$ will be able to take greater advantage of the many opportunities for presenting Britain to the world through this medium.

\section{SCIENTIFIC RESEARCH IN NEW ZEALAND}

$\mathrm{T}$ HE report of the Department of Scientific and Industrial Research, New Zealand, for the year ended March 31, 1960, shows gross expenditure of $£ 1,812,000$, and staff at April 1, 1960, totalling 1,121, including 401 professional, compared with 1,067 and 390 , respectively, in the previous year*. It includes the Minister's statement, the report of the Council for Scientific and Industrial Research, the Secretary's report, notes on the work of the several branches and divisions as well as of the jncorporated research associations and on grant-aided research in other institutions, and also lists of publications. The second annual report of the Ross Dependency Research Committee is appended, to which also is attached a list of publications. A survey of the work of the Department made by the Council during the past two years led to the conclusion that in most branches the balance was held between ad hoc and long-term basic research, though in a few units basic research could with advantage be strengthened. Over the past decade the number of scientific staff employed by the Department has remained virtually static and there is virtually no scope for readjustments to meet the demands of new developments in nuclear science, oceanography, geothermal or Antarctic activities. Limitations of staff and finance debar the Department from exploiting fully the scientific opportunities to assist primary and manufacturing industry, and the Council estimates that full implementation of the present programme of work requires an increase of 40-50 staff per annum and of expenditure from $£ 1,812,000$ in $1959-60$ to $£ 2,090,000$ in $1960-61$, $£ 2,133,000$ in $1962-63$ and $£ 2,265,000$ in 1964-65, assuming that costs and salary scales remain at the 1959 level. Provision of $£ 200,000$ per annum for

* New Zealand. Report of the Department of Scientiflc and Industrial fiesearch for the year ended 31 March, 1960. Pp. 128. (H. 34.) (Wellington: Government Printer, 1960.) 48. 6d. buildings over the next five years is also recommended, apart from the cost of some major items of equipment such as a small nuclear reactor and electronic computer. Establishment of a National Research Organization as an independent organization responsible for the main research functions of Government is recommended as likely to lead to greater efficiency, better co-ordination in existing research programmes and greater flexibility in meeting future needs, and finally the urgent need for a thorough revision of professional salaries is emphasized.

Since 1949-50. the expenditure of the Department has risen from $£ 959,000$ to $£ 1,658,000$ in $1958-59$, and was only $0 \cdot 146$ per cent of the gross national product, compared with 0.173 per cent, and the professional staff numbered 383 compared with 363 . Research grants to universities, research institutions, otc., in 1959-60 totalled $£ 172,272$, but the only branches of the Department in which expenditure exceeded $£ 100,000$ were the Dominion Laboratory $(£ 194,180)$, Dominion Physical Laboratory $(£ 199,203)$, Geological Survey (£102,750), Geophysics Division $(£ 111,206)$, Grasslands Division $(£ 108,078)$ and Soil Bureau (£105,512).

The Secretary's report refers briefly to some of the research work of the year. An extensive programme of tests on the durability of paints showed that poor workmanship and inferior quality of paint were the prime causes of poor durability, with excessive weathering of priming coats and the dip-treatment methods of timbor preservation as contributory factors. More careful attention to surface preparation is required when using synthetic finishes. Use of sawdust or shavings from arsenic-treated timber in smoke curing has been shown to constitute a toxicity hazard through deposition of arsenic on the food. The analysis of steel and reinforced-concrete frame structures is being continued, and the use of an analogue computer offers a 